\title{
EFFECT OF CYCLIC LOADING ON FRACTURE STRENGTH OF ENDODONTICALLY TREATED TEETH RESTORED WITH CONVENTIONAL AND ESTHETIC POSTS
}

\author{
EFEITO DA CARGA CÍCLICA NA RESISTENNCIA DE DENTES TRATADOS ENDODONTICAMENTE \\ RESTAURADOS COM PINOS DENTÁRIOS CONVENCIONAIS E ESTÉTICOS
}

\begin{abstract}
Anuar Antônio XIBLE ${ }^{1}$, Rudys Rodolfo de JESUS TAVAREZ ${ }^{2}$, Carlos dos Reis Pereira de ARAUJO ${ }^{3}$, Paulo César Rodrigues CONTI ${ }^{4}$, Wellington Cardoso BONACHELLA ${ }^{4}$
\end{abstract}

\begin{abstract}
1- DDS, MS, PhD, Professor, Department of Prosthodontics, Dental School, Espírito Santo Federal University, Brazil.
2- DDS, MS, PhD, Professor, Department of Dental Materials, Dental School, Maranhão Federal University, Brazil.

3- DDS, MS, PhD, Adjunct Professor, Department of Prosthodontics, Bauru Dental School, University of São Paulo, Brazil.

4- DDS, MS, PhD, Associate Professor, Department of Prosthodontics, Bauru Dental School, University of São Paulo, Brazil.
\end{abstract}

Corresponding address: Anuar Antônio Xible - Av. Prof. Elpídio Pimentel, 420/102 - Mata da Praia - Vitória - ES - Cep.: 29065-060 Tel: (5527) 3181-0046 / (5527) 3314-0936 /(5527) 9949-3867

Received: December 21, 2004 - Modification: June 16, 2005 - Accepted: May 3, 2006

\begin{abstract}
$I$

ntroduction: Esthetic post and core systems were recently introduced. There are few reports regarding their behavior under cyclic loading. Objectives: This study compared the effect of cyclic loading on survival rate, residual strength and mode of fracture of endodontically treated teeth restored with esthetic and direct metallic post systems subjected to mechanical cyclic loading. Materials and Methods: Thirty canines were endodontically treated, decoronated and prepared for metal free ceramic crowns, leaving $1.5 \mathrm{~mm}$ of dentin for ferrule effect. They were distributed in 3 groups and restored as follows: group 1 with zirconia posts (Cosmopost) and glass-ceramic cores (IPS Empress Cosmopost); group 2 with fiber reinforced composite posts (FibreKor) and group 3 with titanium posts (AZthec Anchor). Direct resin composite (Build It FR Resin Composite) was used as core in groups 2 and 3. All specimens were restored with all ceramic crowns (IPS Empress 2). A resin cement/adhesive system (Cement It/Bond It Primer A+B) was used to lute the posts to root canals and metal free porcelain crowns to the teeth preparation. Specimens were subjected to mechanical load of $250 \mathrm{~N}$ for 500,000x at a frequency of $1.7 \mathrm{~Hz}$ and then to static load until failure in a universal testing machine. Data were analyzed using One-way ANOVA and Fischer Exact tests $\alpha=0.05$. Results: All groups had $100 \%$ survival rate after cyclic loading; fracture strength values (SD) in N were: group $1=886.5(170.6)$, group $2=762.2(113.6)$ and group $3=768.9(72.9)$; there was no difference among groups $(\mathrm{p}=0.08)$; the percentage of mode of favorable fracture found was: group $1=60 \%$, group $2=90 \%$ and group $3=50 \%$; there was no correlation between the mode of failure and post and core system used $(\mathrm{P}=0.142)$. Conclusions: Esthetic post and core systems showed statistically equivalent fracture strength values, mode of failure and survival rate compared to conventional direct metallic post and resin composite core system after cyclic loading. Uniterms: Dental porcelain; Dental stress analysis; Ceramics; Composite resins; Dental pins; Stress, mechanical.
\end{abstract}

\footnotetext{
RESUMO

I

ntrodução: Os sistemas de núcleos intra-radiculares estéticos foram recentemente introduzidos no mercado. Não existem muitos trabalhos na literatura comparando seu comportamento em relação aos sistemas de pinos metálicos convencionais quando submetidos à testes com carga cíclica. Objetivos: este estudo comparou a taxa de sobrevivência, resistência à fratura e modo de fratura de dentes tratados endodonticamente reconstruídos com sistemas de núcleos intra-radiculares metálicos convencionais e estéticos, restaurados com coroas de porcelana pura e submetidos à carga cíclica. Materiais e Métodos: trinta caninos tiveram as coroas removidas 1,5mm acima da junção cemento-esmalte e preparados para coroa de porcelana pura deixando 1,5mm de dentina acima do término do preparo. Os dentes foram distribuídos em 3 grupos de 10 . O grupo 1 foi restaurado com pinos de cerâmica de zircônia e núcleos de preenchimento em cerâmica vítrea termo-injetada. O grupo 2 foi restaurado com pinos de resina composta reforçada por fibra de vidro e o grupo 3 com pinos de titânio. Nos grupos 2 e 3 foi usada resina composta reforçada com fibra de vidro como material para núcleo de preenchimento; os dentes foram restaurados com coroas totais e tanto os pinos quanto as coroas de porcelana foram cimentados com um sistema de cimentação resinosa de polimerização dupla. Os espécimes foram incluídos em resina acrílica e submetidos à uma carga de $250 \mathrm{~N}$ por 500,000 ciclos, numa freqüência de 1,7Hz sendo em seguida submetidos à carga estática em uma máqina de testes universal até a falha. Os dados foram analisados estatisticamente com os testes ANOVA a 1 critério e Exato de Fischer $(\alpha=.05)$. Resultados: a taxa de sobrevivência foi de 100\%; os valores de resistência à fratura em N (DP) foram: grupo 1 = 886,50(170,6), grupo 2 = 762,2(113,6) e grupo $3=768,9(72,9)$. Não houve diferença estatística de resistência à fratura entre os grupos $(\mathrm{P}=0.08)$. $\mathrm{O}$ percentual de modo de fratura favorável encontrado foi: grupo $1=60 \%$; grupo $2=90 \%$ e grupo $3=50 \%$. Não houve correlação entre o tipo de pino e modo de fratura ( $\mathrm{P}=0.142$ ). Conclusão: dentes restaurados com sistemas de núcleos intra-radiculares estéticos e coroas totais de porcelana tiveram as mesmas taxas de sobrevivência, valores de resistência à fratura e modo de fratura que os metálicos convencionais diretos após aplicação de carga cíclica. Unitermos: Porcelana dentária; Análise do estresse dentário; Cerâmicas; Resinas compostas; Pinos dentários; Estresse mecânico.
} 


\section{INTRODUCTION}

A large variety of materials and techniques to restore structurally compromised endodontically treated teeth is presently available in the literature ${ }^{1,10,11,17,20,24,26,30}$. The performance of direct metallic posts, particularly, is well documented in the literature and their success rates vary according to studies ranging from $69 \%$ after 5 years to $92 \%$ after 10 years follow-up, close to results demonstrated by cast post and cores ${ }^{13}$. Recently, it has been suggested that fiber reinforced resin composite posts (FRC) and zirconium dioxide posts could adequately replace the conventional metallic, both cast and direct posts ${ }^{1,10,11,24}{ }^{26}$.The main advantage of non-metallic posts is the solution esthetic problems as the grey shade observed in translucent crowns when used in association with metallic post and core foundation to restore endodontically treated teeth ${ }^{1,10,11,24,26}$.

Numerous studies have remarked the positive properties of FRC posts $2,3,9-12,16,20,21,23,26$. Their association with resin composite core, besides esthetic properties and low cost, would provide a positive behavior of the tooth/post assembly, since its modulus of elasticity (13.5 GPa) is closer to the human dentin tissue ${ }^{19,22}$. Also, the mechanical properties are enough to support masticatory loads and prevent catastrophic failure of the tooth in case of fracture. It could be obtained due to the stress dissipation along the root, generating a pattern of fracture usually at the cervical portion of the remaining tooth $^{9,10,16,21,23,26}$. On the other hand, the use of zirconia posts has been questioned due to their mechanical properties such as high modulus of elasticity (200 GPa), stiffness and hardness, which could be associated with catastrophic failures of the root and difficult retrieval from remaining tooth besides its high cost. 9, 21, 23, 26 Conversely, these properties are also related to an increase in tooth strength, which is also required when someone selects a post ${ }^{8,10,14,17,24,28}$.

Laboratory studies have shown close similarities regarding the fracture strength values of endodontically treated teeth restored with cast post and cores and prefabricated metallic posts and resin composite core systems when subjected to static or cyclic loading ${ }^{10,11,13,15,23,25,28}$. More recently, the esthetic posts have been compared to conventional posts in laboratory studies. Heydecke and Strub $^{14}$, and Butz, et al. ${ }^{8}$ used a load of $30 \mathrm{~N}$ for 1.2 million cycles in artificial oral environment to test the survival rate of teeth restored with Titanium (TI) posts and composite resin (RC) cores, cast post and cores (CPC), Zirconia (ZI) posts either with RC and glass-ceramic (GC) cores. Final restorations were made of metal crowns luted with glass-ionomer cement. Survival rate was $96 \%$ for TI/RC group, $66.6 \%$ for $\mathrm{ZI} / \mathrm{RC}$ and $100 \%$ for ZI/GC group and 96\% for CPC group. They concluded that ZI posts show a better performance than direct metallic posts. Strub, et al. ${ }^{28}$ compared the survival rate and residual strength of teeth restored with CPC, ZI and FRC posts with RC cores and ZI with GC cores. Values obtained were $90 \%$ and $1270 \mathrm{~N}$ for the first group, $80 \%$ and $1494 \mathrm{~N}$ for second group, $60 \%$ and $1146 \mathrm{~N}$ for third group and $100 \%$ and $463 \mathrm{~N}$ for the ZI/GC group. Heydecke, et al. ${ }^{14}$, in 2002, tested the fracture strength of teeth restored with ZI posts either with RC and GC as core, TI posts and RC cores and CPC after 1,2 million cycles of $30 \mathrm{~N}$ of load at $1.3 \mathrm{~Hz}$ and thermal cycling $\left(5^{\circ} \mathrm{C}\right.$ to $55^{\circ} \mathrm{C}$ ). Survival rates were $93.8 \%$ for groups 1 and 2 , $100 \%$ for groups 3 and $87.5 \%$ for group 4 . The mean fracture strength was $450 \mathrm{~N}, 503 \mathrm{~N}, 521 \mathrm{~N}$ and $408 \mathrm{~N}$ respectively. Based on the above results, authors concluded that zirconia posts associated either with glass-ceramic or composite resin cores are suitable for clinical use.

Other essay set-ups can be used to assess the behavior of post and core systems under cyclic loading. With a load of $250 \mathrm{~N}$ for 400,000 cycles at $2 \mathrm{~Hz}$ frequency, Mannocci, et al. ${ }^{21}$ tested the survival rate of teeth restored with two types of FRC and ZI posts and RC core systems compared with a control group with no post and core reconstruction, and leucite reinforced porcelain crowns luted with resin cement. A single root fracture at the cervical portion location in the teeth of each FRC group compared with 6 fractures mainly located at medium portion of root of zirconia group and 10 fractures of control group led the authors to assert that the FRC posts may prevent or at least favor restorable root fractures. In another study, Dietschi et $\mathrm{al}^{9}$ used a load of $70 \mathrm{~N}$ for 250,000 cycles at a frequency of $1.5 \mathrm{~Hz}$ and 5,000x thermal cycles $\left(5^{\circ} \mathrm{C}-55^{\circ} \mathrm{C}\right)$ to compare the effect of cyclic loading on the interface between root dentin/resin cement/post. They used teeth prepared for full crown restoration with no remaining dentin left for ferrule effect that were restored with FRC, ZI or metallic posts and RC as core material. No crown was used as final restoration, so that the load was applied directly on the post/core surfaces. At Scanning Electronic Microscopy examination, the percentage of gap in the interface between root/dentin/resin cement/post surfaces was measured and ZI posts group had the highest gap index as long as the FRC posts showed the lowest gap percentage among groups tested. Authors concluded that the highest gap formation percentage was related to the dissimilar stiffness of ZI posts and dentin. Conversely, the lowest gap formation was related to the similar stiffness of FRC posts and dentin.

A critical appraisal of the use of cyclic loading to compare the performance of posts in laboratory studies shows a large variety of parameters of essays set-up. Number and frequency of cycles and load used derives from several sources and are usually inconstant in the studies, impairing the inference and comparison of results from different studies ${ }^{5,8,9,13,14,16,18,21,25,28,29}$. Other factors should also be highlighted, such as the presence of a minimum ferrule length of $1.5 \mathrm{~mm}$ in tooth preparation. Many studies have shown an increase in fracture strength of endodontically treated teeth restored with post systems due to the presence of $1.5 \mathrm{~mm}$ of coronal remaining dentin ${ }^{4,15}$. Other factors include the use of a crown as final restoration as well as its material and cement used to lute crowns and posts. The need of crowns as final restorations to closely simulate the clinical scenario has been extensively discussed ${ }^{8,9}$. In some studies, metallic crowns were used as final restorations and conventionally cemented ${ }^{16,23,25}$. Previous pilot studies were conducted and it was found that cyclic loading using $250 \mathrm{~N}$ for 500,000 cycles at $1.7 \mathrm{~Hz}$ frequency was enough to lower the fracture strength of endodontically treated teeth restored 
with esthetic posts.

Few studies are presently available in the literature where ZI, TI and FRC posts are compared. Therefore, the aim of this study was to investigate the survival rate, fracture strength and mode of failure of teeth reconstructed with direct metallic and esthetic posts, restored with all ceramic crowns luted with resinous cement and subjected to cyclic loading.

\section{MATERIALS AND METHODS}

Thirty sound caries free human canines, kept in $0.1 \%$ thymol for at most 6 months, were cut to a flat plane $1.5 \mathrm{~mm}$ coronal to the buccal cementoenamel junction (CEJ) and perpendicular to the tooth long axis, using a KS-7 supercoarse diamond wheel (Brasseler; Germany) at $300 \mathrm{rpm}$ with a load of 800 gr under copious irrigation. A1.0-mm wide shoulder was placed in the buccal-lingual aspects and $0.8 \mathrm{~mm}$ in the mesio-distal aspects using a Premier Two Striper diamond bur (Brasseler; USA). This preparation was terminated at the buccal CEJ, providing a 1.5-mm ferrule effect in dentin. Root canals were enlarged using Kerr files (Kerr, Switzerland) up to 40 and $2.5 \%$ sodium hypochlorite for irrigation, then obturated using gutta-percha and calcium hydroxide (Sealapex; Kerr, USA) with the lateral condensation technique. Teeth were divided into three groups with 10 teeth each according to the stratified method and classified according to the post system used (Figure 1): group 1 - zirconia ceramic-based posts (ZI) (Cosmopost; Ivoclar Vivadent, Liechtenstein), group 2-glass fiber reinforced resin composite posts (FRC) (FiberKor; Pentron, USA) and group 3 - titanium posts (TI) (Aztech Anchor; Dentatus, USA). The teeth of each group had their root canals prepared for posts with the drills of the respective systems to $10.5-\mathrm{mm}$ length. The total length of posts was set for $15 \mathrm{~mm}$, with the final $4.5 \mathrm{~mm}$ of the coronal part retaining the core build up.

For group 1, cores were obtained by indirect technique. Using metallic posts and polyvinylsiloxane (Express; 3M ESPE, USA), impressions were taken from the postholes. Type IV stone (Die Stone Velmix Classic; Kerr, USA) was poured and allowed to dry. Zirconia posts were positioned into postholes of casts and cores were manually waxed using Pro Art wax (Ivoclar Vivadent), with $4.5 \mathrm{~mm}$ height and lingual aspect with a $45^{\circ}$ inclination. Following the manufacturer's instructions, they were individually invested with IPS Empress 2 Special Investment (Ivoclar Vivadent), heat pressed with IPS Empress Cosmopost glass-ceramic (Ivoclar Vivadent), then divested and fit checked (Accufilm IV; Parkell, USA) to the stone dyes. The ceramic post and cores were cleaned with isopropyl alcohol in an ultrasonic device for $15 \mathrm{~min}$ and completely air-dried with oil-free air.

For luting procedures of ceramic post and cores of group 1 , the internal coronal parts of ceramic posts made out of the heat-pressed glass ceramic were etched with 5\% hydrofluoric acid (IPS Ceramic; Ivoclar Vivadent) for $1 \mathrm{~min}$, thoroughly rinsed and completely air-dried with oil-free air. One coat of Monobond S (Ivoclar Vivadent, Liechtenstein) silane was applied, gently air-dried and two coats of dual cure bonding system (Bond-It A + B; Pentron) applied consecutively according to manufacturer's instructions.

For groups 2 and 3 the FRC and TI posts were cleaned with $37 \%$ phosphoric acid (Unietch; Ivoclar Vivadent) that was applied for 20 seconds, thoroughly rinsed and completely air-dried with oil-free air and one coat of the bonding system (Bond-It A + B, Pentron) was applied.

The following steps were common for all groups: postholes were etched with 37\% phosphoric acid (Unietch; Ivoclar Vivadent), thoroughly rinsed and air-dried with oil-free air and paper points until dentin was slightly wet. The bonding agent (Bond-It A+B, Pentron) was applied, slightly air-dried for 10 seconds and excesses removed with paper points used to remove the bonding agent. The dual cure luting agent (Cement It Universal C \& B; Pentron) was applied to the posts and inserted in the postholes using a lentulo drill, followed by the posts. The excess cement was removed after $1 \mathrm{~min}$ and an Astralis (Ivoclar Vivadent; USA) light curing unit, with light intensity of $450 \mathrm{~mW} / \mathrm{mm}^{2}$ was used for initial light-curing of the cement. The light source was positioned at $10 \mathrm{~mm}$ from the cement layer for 40 seconds in the mesial and distal aspects of the teeth.

For core build up in groups 2 and 3 a dual cure fiber reinforced resin composite (FR Build-It Fiber Reinforced Core; Pentron) was inserted in a plastic form and mounted on the teeth and light-cured for 40 seconds, in the mesial, distal, buccal and lingual aspects of teeth. After $4 \mathrm{~min}$, the plastic forms were removed and specimens were stored in distilled water.

After 24 hours, crown preparations of all specimens were completed using a diamond (KS2; Brasseler) and carbide (H158-014; Brasseler) burs leaving a 1.0-mm rounded shoulder in bucco-lingual and 0.8-mm in mesio-distal aspects. The wall convergence had approximately 6 degrees and preparations yielded $6 \mathrm{~mm}$ height and a $45^{\circ}$ inclination in the lingual aspect. (Figure 2) Using polyvinylsiloxane (Express; 3M), impressions were taken from the preparations, and dies obtained using Type IV stone (Die Stone Velmix Classic; Kerr).

Using a silicon stent, 30 single customized crowns were waxed up using Pro Art wax (Ivoclar Vivadent; Germany), to yield a crown height of $8.0 \mathrm{~mm}$ from the CEJ, and lingual aspect

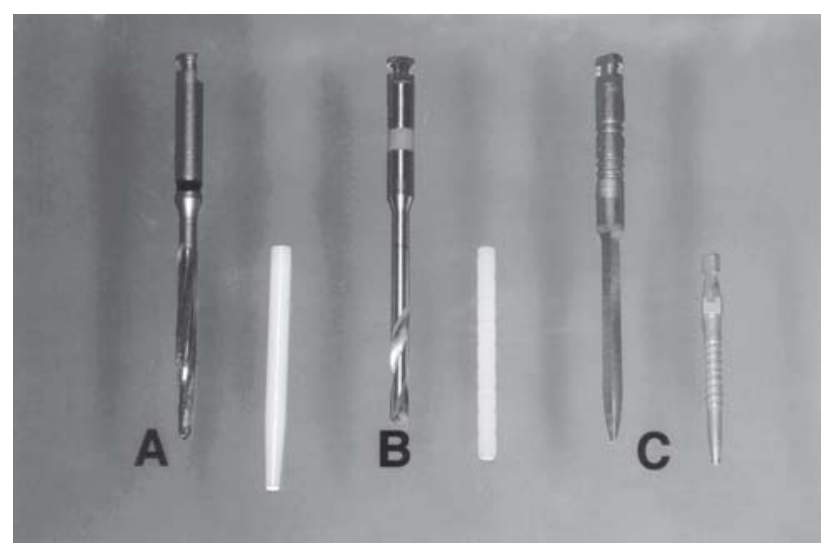

FIGURE 1- Post systems used in the study. A- Zirconia Posts; B- Fiber Reinforced Resin Composite Posts and C- Titanium Posts 
with a $45^{\circ}$ inclination. They were individually invested with IPS Empress 2 Special Investment (Ivoclar; Germany) and heat pressed with IPS Empress 2 dissilicate glass-ceramic (Ivoclar; Liechtenstein) following the manufacturer's instructions. After bench cooling, specimens were divested, air particle abraded with 50 $\mathrm{mm}$ roller blast under a 2.8 Bar pressure and fit checked with Accufilm IV (Parkell; Farmingdale, NY, USA) to the stone dyes. All adjustments were performed using a diamond bur ( $N^{\circ}$ 1111; KG Sorensen, Brazil) under copious water irrigation. One operator checked the crown adaptation with a $n^{\circ} .5$ probe (Hu Friedy; USA), using optical lens $4 \mathrm{X}$ magnification. Crowns were considered adapted when no gap was probed between the crown and the dye. The crowns were cleaned with isopropyl alcohol in an ultrasonic device for $15 \mathrm{~min}$ and dried with oil-free air. A glaze mass (IPS Empress Universal Glazing Paste; Ivoclar Vivadent, Liechtenstein) was fired on crowns using a porcelain furnace (Vita Vacumat 40; Vita, Germany) and adaptation was checked again following the same steps cited above.

For crown cementation, their internal surfaces were treated with 5\% hydrofluoric acid for 20s, washed out and dried with oil-free air. Monobond S (Ivoclar Vivadent) silane was applied, left to dry for $1 \mathrm{~min}$ and dried with oil free air. Bonding agent Bond 1 A+B (Pentron; USA) was applied and dual cure cement Cement It (Pentron; USA) applied to the internal walls of crowns and positioned on specimens. Crowns were kept under finger pressure for $5 \mathrm{~min}$.

To perform the cyclic test, twenty four hours after crown cementation, specimens were placed in aluminum bars, and embedded in acrylic resin (Formatray; Kerr, USA) to a depth $2 \mathrm{~mm}$ below the finishing line of crowns, with their long axes in a $45^{\circ}$ inclination with horizontal plane (Figure 3). Acrylic boxes were built around specimens so that they could be immersed in distilled water during the cyclic load. A customized fatigue machine (Restorative and Biomaterials Laboratory at Goldman School at Boston University) was used with a metallic sphere with 5-mm diameter contacting the crowns at $3 \mathrm{~mm}$ below the incisal edge (Figure 4). The cyclic test consisted of 500,000 cycles using a load with a peak of $250 \mathrm{~N}$ at a frequency of $1.7 \mathrm{~Hz}$ applied at an angle of $130^{\circ}$ inclination with specimens'

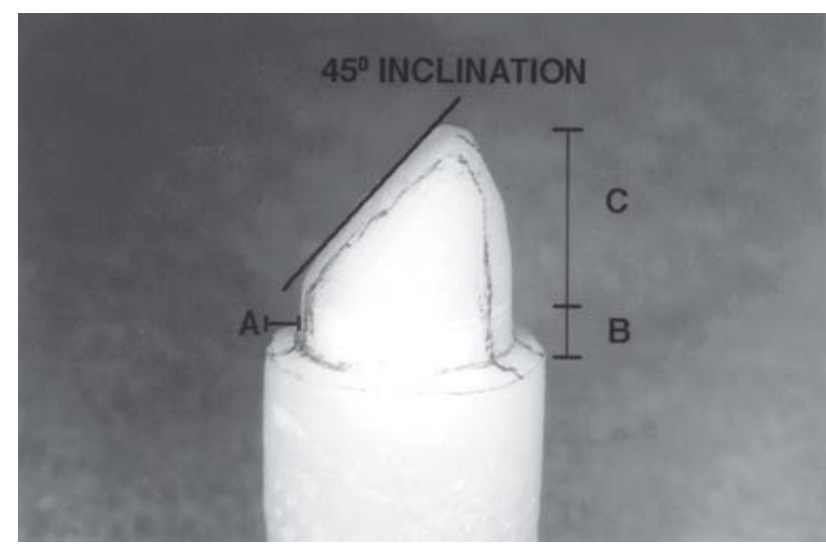

FIGURE 2- Final preparation display with corresponding measures: A - Lingual preparation with $0.8 \mathrm{~mm}$ width; BRemaining dentin for the ferrule effect of crowns with $1.5 \mathrm{~mm}$ height and C- Core with $4.5 \mathrm{~mm}$ height long axis. After cyclic loading test, specimens were examined under 20X magnification in a light microscope (Swift Instruments; USA) to assure that no root flaws or fractures were present.

To perform the static loading test, all specimens were coupled in a universal testing machine (Instrom; Model 4202, USA) and a metal cylinder was positioned touching one point of the lingual aspect of the crowns, 3mm below the incisal edge and $130^{\circ}$ to the specimens' long axis (Figure 5). Using a $10 \mathrm{KN}$ cell and a crosshead speed of $0.5 \mathrm{~mm} / \mathrm{min}$, load was

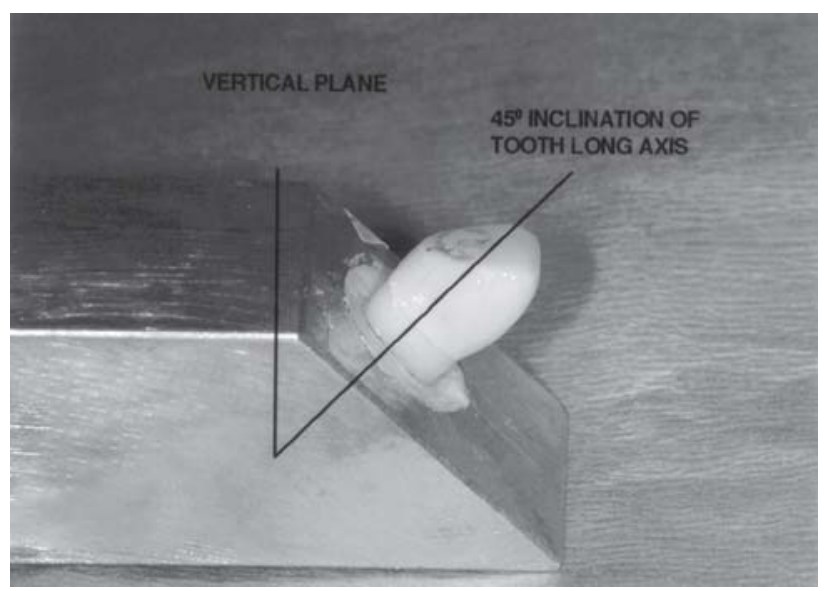

FIGURE 3- Specimen embedded in acrylic resin in the aluminum block. Lines define the inclination of tooth long axis

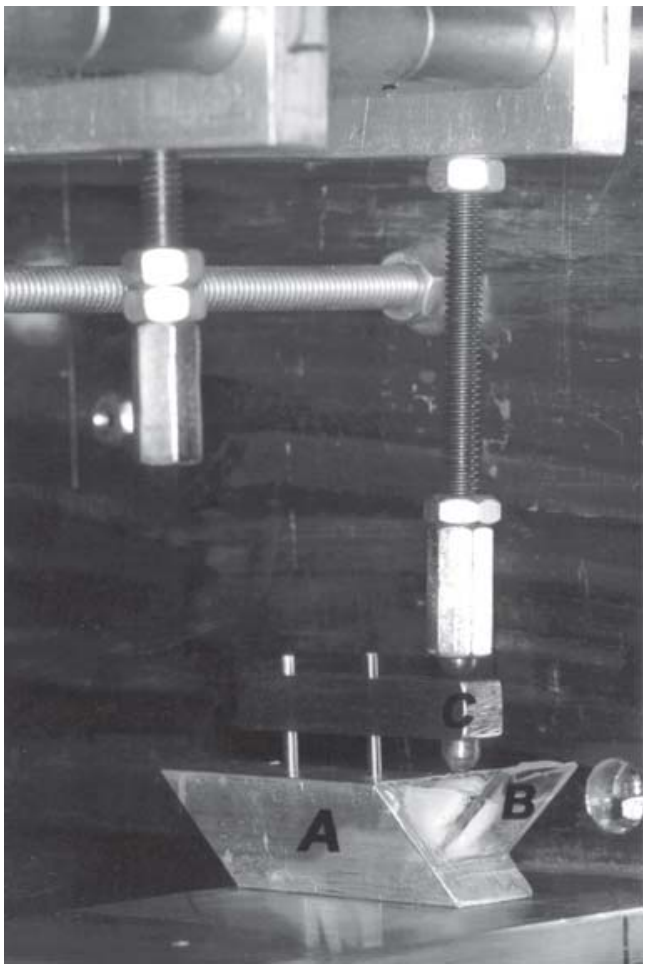

FIGURE 4- Specimen positioned in the cyclic machine for fatigue test. A- Aluminum block; B- Acrylic box containing distilled water surrounding the specimen and CMechanical device containing the sphere placed on the crown lingual surface 
applied until failure of specimens. The maximum load was recorded in $\mathrm{N}$. Specimens were removed from the acrylic base and examined under 20X stereomicroscope (Swift Instruments) for analysis of mode of fracture. One doubleblinded examiner assessed the fracture as favorable when it occurred until $1 \mathrm{~mm}$ below the resin acrylic margin and catastrophic when occurred below this level toward the root apex (Figure 6).

\section{STATISTICALANALYSIS}

SPSS for Macintosh Version 11.0 (SPSS Inc.; USA) was used to treat the data. One-Way ANOVA test was performed to detect differences for maximum load to fracture. Fischer Exact test was used to detect association between mode of fracture and type of posts. A significance level of $\alpha=0.05$ was used for all comparisons.

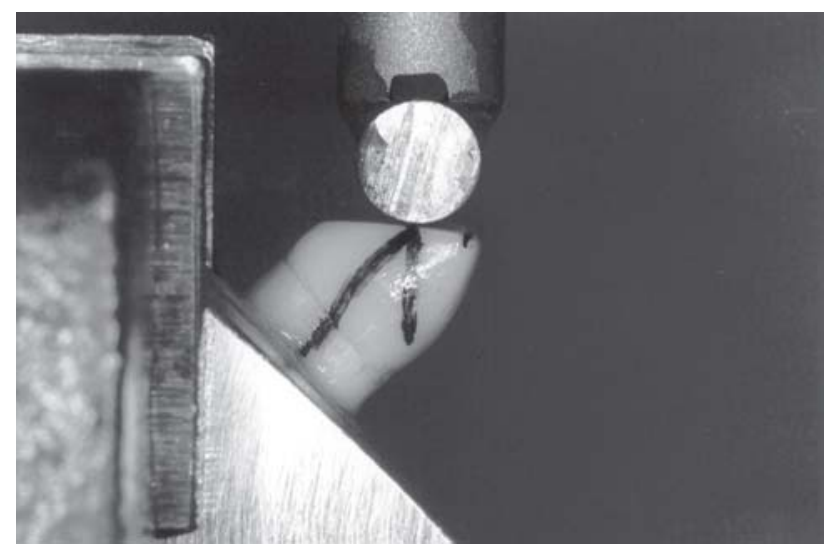

FIGURE 5- Specimen mounted in a universal testing machine for static loading test. Load was applied $45^{\circ}$ with the tooth long axis, in one point of the crown surface

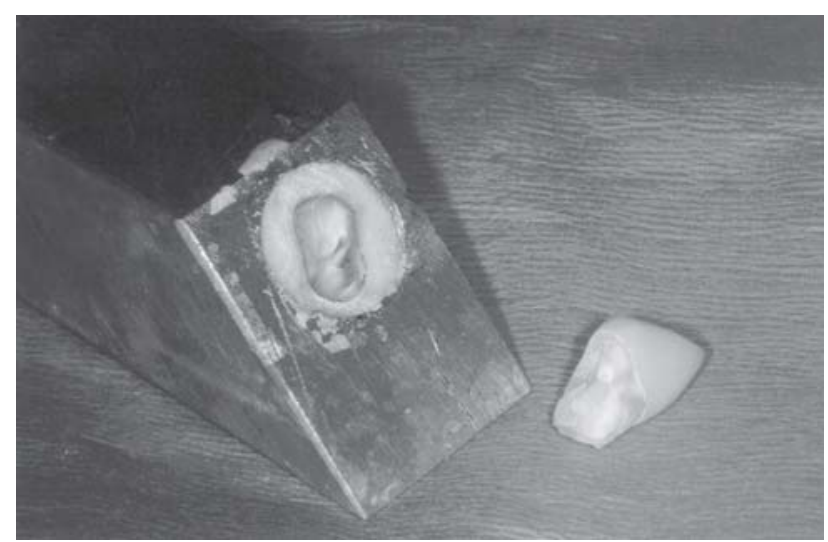

FIGURE 6- Catastrophic fracture mode in the ZI group. The line of fracture is located more than $1 \mathrm{~mm}$ below the acrylic level

\section{RESULTS}

No specimens failed during cyclic loading test leading to a $100 \%$ survival rate in all groups. Mean fracture load in N (SD) were: group $1=886.5(231.2)$; group $2=762.2$ (113.6) and group $3=768.9$ (72.9). One-way ANOVA test revealed no difference among groups $(\mathrm{P}=0.08)$ (Table 1$)$. The prevalence of mode of fractures was $60 \%$ of favorable and $40 \%$ of catastrophic fractures for ZI group, 90\% of favorable and $10 \%$ of catastrophic fractures for FRC group and $50 \%$ of each mode of fractures in the TI group. There was no correlation between the fracture mode and type of posts $(\mathrm{P}=0.142)$ (Table 2).

\section{DISCUSSION}

Previous reports ${ }^{21}$ and pilot studies showed that the cyclic test used in this study could lower specimens' strength. However, it was expected that groups were affected in different levels, since they were reconstructed with materials that exhibit

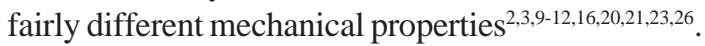

Some factors might have contributed in different ways for the equivalence among groups in this study, including the retention of post to root canal and the adhesion between porcelain crowns to the core material. Al-Harbi and Nathanson $^{2}$ found that FRC and TI posts had a higher retention to root canal than ZI posts. In the present study, intra-canal post retention might have favorably influenced the strength of FRC and TI post groups. On the other hand, porcelain cores might have favorably played a significant role in the fracture strength of specimens of the ZI group. First, by the adhesion with porcelain crowns provided by the resin cement and hydrofluoric acid etching/silane application conducted in the glass ceramic surface before cementation in the ZI group, what provides a stronger bond than that provided by RC cores and resin cement in group 2 and $3^{6,7,30}$, and second, the ceramic core structural strength by itself. The glass ceramic (IPS Empress Cosmo) has superior mechanical properties than RC of cores of FRC and TI groups $^{1,26,30}$.

When compared to other studies, Heydecke and Strub ${ }^{14}$ used $30 \mathrm{~N}$ for 1.2 million cycles to test specimens reconstructed with zirconia posts and glass ceramic cores and restored with metal crowns luted with zinc phosphate cement and found fracture strength values for static load of $512 \mathrm{~N}$; using the same methodology, Butz, et al. ${ }^{8}$ found $378 \pm 64$ N. Strub, et al. ${ }^{28}$ also found $1146.7 \pm 1182 \mathrm{~N}$ and Pontius and Hutter ${ }^{25}$ found $1494.3 \pm 333.5 \mathrm{~N}$. The authors did not provide information regarding teeth dimensions and preparations, but used Procera ${ }^{\circledR}$ copings as final restoration and Panavia 21 ${ }^{\circledR}$ to lute crowns.

Strub, et al. ${ }^{28}$ also tested specimens reconstructed with FRC posts and RC cores covered with Procera ${ }^{\circledR}$ copings luted with resinous cement, for 1.2 million cycles in a masticatory simulator and found strength values of $1146.7 \pm$ $182.6 \mathrm{~N}$ while in the present study it was found 762.2 \pm 113.6 N. Authors did not specify the load used in their work. 
Heydecke and Strub ${ }^{14}$ tested specimens reconstructed with TI posts and RC cores, subjected to 1.2 million cycles using load of $30 \mathrm{~N}$, covered with metal crowns luted with zinc phosphate cement and found fracture strength of $503 \mathrm{~N}$. Butz et $\mathrm{al}^{8}$ used the same methodology and found $425 \pm 155 \mathrm{~N}$. Strub, et al. ${ }^{28}$ used a masticatory simulator for 1.2 million cycles in specimens covered with Procera ${ }^{\circledR}$ copings luted with resinous cement, and found fracture strength values of $1038 \mathrm{~N}$, compared to $768.9 \pm 72.9 \mathrm{~N}$ in the present study.

If compared to other studies, some differences in the methodology may have contributed for the results: in the present study, the $100 \%$ survival rate after cyclic loading test allowed a moderate intra-group standard deviation. In some studies $^{8,21}$, the fracture strength values for specimens that failed during cyclic loading test were assigned as zero $(0 \mathrm{~N})$, remarkably increasing the final strength results among groups. Also, instead of crowns luted with conventional cement, in the present study, the hydrofluoric acid etching followed by silane layer before cementation made in the internal surface of the porcelain crowns may have contributed for the increase in their adhesion with teeth and cores, improving the fracture strength of specimens.

Following current concepts of treatment of endodontically treated teeth with post and core systems, $1.5 \mathrm{~mm}$ of dentin was left above the finishing line of the preparation to provide the ferrule effect. Many previous studies strongly suggest that it increases the fracture strength of specimens ${ }^{4,15,27}$. This concept was not followed by Dietschi, et al. ${ }^{9}$, Mannocci, et al. ${ }^{21}$, and Pontius and Hutter ${ }^{25}$.

The fracture mode found in the three groups in the present work was numerically quite dissimilar but no differences among groups were demonstrated $(\mathrm{P}=0.142)$. There was not a consistent prevalence of a specific mode of fracture in the groups, although, numerically, a higher number of restorable fractures were found in the FRC post group (90\%), which was similar to Pontius and Hutter ${ }^{25}$ who found $100 \%$ of reparable fractures. The present study observed $60 \%$ of restorable fractures for the ZI group, while Heydecke and Strub ${ }^{14}$ found $86.5 \%$ and Butz, et al. ${ }^{8}$ found $80.25 \%$. For the TI group of the present study, there were $50 \%$ of reparable fractures that were not consistent with Heydecke and Strub ${ }^{14}$ who reported 0\%, and Butz, et al. ${ }^{8}$ who found $13.5 \%$ of reparable fractures in their studies.

Much attention is paid to the set-up of the fatigue test. Previous pilot studies demonstrated that $30 \mathrm{~N}$ load for $1,000,000$ cycles was not enough to cause weakening effect on fracture strength of endodontically treated teeth restored with any of the systems tested. On the contrary, $250 \mathrm{~N}$ load for 500,000 cycles caused a lowering in the fracture strength of specimens at a rate between $20 \%$ and $30 \%$. Therefore, many differences observed among other studies and the present study may be attributed to the differences in the cyclic load set-up adopted. Other factors should be highlighted such as post design, material used to make crowns, cement used to lute crows, presence of ferrule effect and root/crown ratio.

Although the results of the present study were not in strict agreement with other studies, it seems that all posts have the same behavior regarding fracture strength. Maybe the ferrule effect and resin cementation on feldspatic crowns were decisive features in the experiment. In spite of equivalence in mode of fracture, a tendency was found of more favorable fracture pattern for the FRC group since it demonstrated a larger number of reparable fractures. For ZI and TI post groups,

TABLE 1- Mean fracture strength ( $\mathrm{N}$ ) and standard deviation for specimens tested

\begin{tabular}{llll}
\hline Groups & Zirconia & Fiber Reinforced Resin Composite & Titanium \\
\hline $\mathrm{N}$ & 10 & 10 & 10 \\
Mean $(\mu)$ & 886.50 & 762.20 & 768.90 \\
Standard Deviation $(\pi)$ & 170.62 & 113.63 & 72.95 \\
\hline
\end{tabular}

*One-Way ANOVA showed no statistical difference among groups $(P=0.08)$

TABLE 2- Fischer Exact Test for association between mode of fracture and type of post

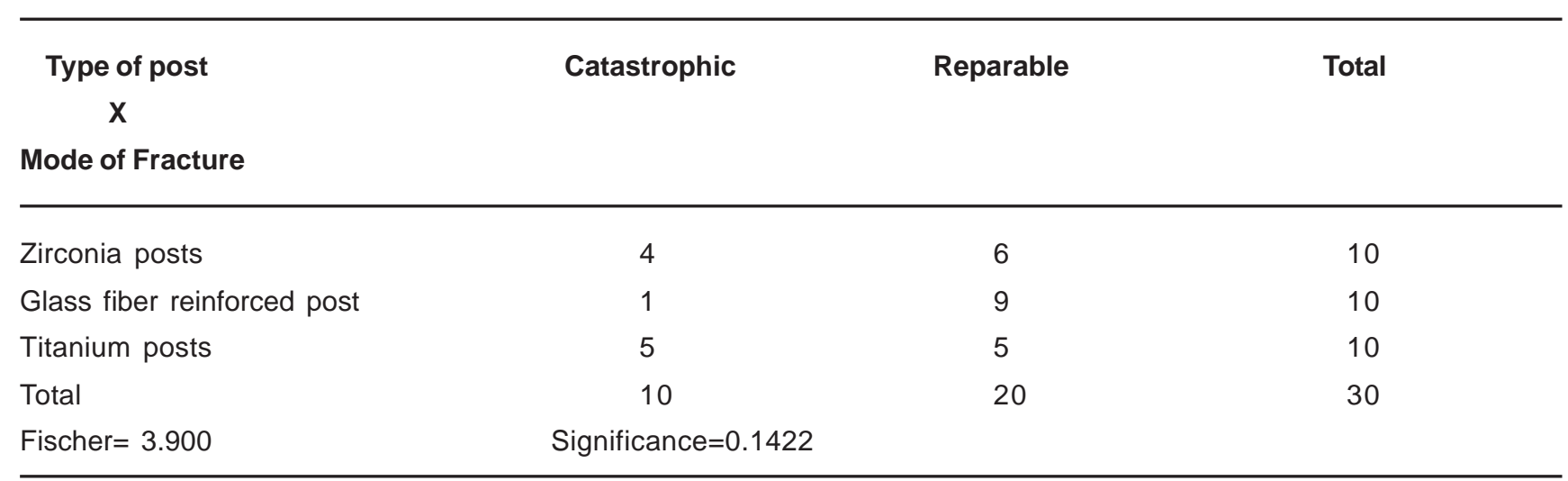


there is no ultimate evidence that they can cause a specific mode of fracture.

\section{CONCLUSIONS}

Within the scope of this study, the following conclusions can be drawn:

1- The fracture strength of teeth restored with esthetic post and core system is statistically equivalent to that obtained for conventional direct metallic post/composite resin core systems when covered with porcelain crowns, after the cyclic loading test $(\mathrm{P}=0.08)$.

2- The type of post and core systems tested did not affect the mode of fracture and survival rate of specimens subjected to cyclic loading test $(\mathrm{P}=0.142)$.

\section{This study was supported by CAPES (DS0106/00)}

\section{REFERENCES}

1- Ahmad I. Ytrium-partially stabilized zirconium dioxide dowels: an approach to restoring coronally compromised non-vital teeth. Int J Periodont Rest Dent. 1998;18:455-65.

2- Al-Harbi F, Nathanson D. In vitro assessment of retention of four esthetic dowels to resin core foundantion and teeth. J Prosthet Dent. 2003;27:547-55.

3- Asmussen E, Peutzfeldt A, Heitmann T. Stiffness, elastic limit, and strength of newer types of endondontic posts. J Dent. 1999;27:275-8.

4- Barkhordar R, Radke R, Abbasi J. Effect of metal collars on resistance of endondontically treated teeth to root fracture. J Prosthet Dent. 1989;61:676-8.

5- Bates J, Stafford G, Harrison A. Masticatory function - a review of literature (II) Speed of movement of mandible, rate of chewing and forces developed in chewing. J Oral Rehabil. 1975;2:349-61.

6- Bona A, Anusavice K, Hood J. Effect of ceramic surface treatment on tensile bond strength to resin cement. Int J Prosthodont. 2002; $15: 248-53$.

7- Bona A, Shen C, Anusavice K. Work of adhesion of resin on treated Lithia dissilicate-based ceramic. Dent Mater. 2004;20:338-44.

8- Butz F, Lennon A, Heydecke G, Strub J. Survival rate and fracture strength of endondontically treated maxillary incisors with moderate defects restored with different post-and-core systems: an in vitro study. Int J Prosthodont. 2001;14:58-64.

9- Dietschi D, Romaelli M, Goretti A. Adaptation of adhesive posts and cores to dentin after fatigue testing. Int $\mathrm{J}$ Prosthodont. 1997; 10:498-507.

10- Fernandes A, Dessai G. Factors affecting the fracture resistance of post-core reconstruceted teeth: a review. Int J Prosthodont. 2001:14:355-63.

11- Fernandes A, Shetty S, Coutinho I. Factors determining post selection: a literature review. J Prosthet Dent. 2003;90:556-62.

12- Goldberg A, Burstone C. The use of continuous fiber reinforcement in dentistry. Dent Mater. 1992;8:197-202.
13- Heydecke G, Peters M. The restoration of endondontically treated, single-rooted teeth with cast or direct post and cores: a systematic review. J Prosthet Dent. 2002;87:380-6.

14- Heydecke G, Strub J. Fracture strength after dynamic loading of endodontically treated teeth restored with different post-and-core systems. J Prosthet Dent. 2002;87:438-45.

15- Isidor F, Brondum K, Ravnholt G. The influence of post length and crown ferrule length on the resistance to cyclic loading of bovine teeth with prefabricated titanium posts. Int J Prosthodont. 1999;12:78-82.

16- Isidor F, Odaman $\mathrm{O}, \mathrm{Br} \varnothing$ ndum $\mathrm{K}$. Intermittent loading of teeth restored using prefabricated carbon fiber posts. Int J Prosthodont. 1996;9:131-6.

17- Kakehashi Y. A new all-ceramic post and core system: clinical, techincal and in vitro results. Int J Periodont Rest Dent. 1998:18:58793

18- Kiliaridis S, Kjellberg H, Wenneberg B. The relationship between maximal bite force, bite force endurance, and facial morphology during growth. Acta Odontol Scand. 1993;51:323-31.

19- Kinney J. Hardness and Young's modulus of human peritubular and intertubular dentine. Arch Oral Biol. 1996;41:9-13.

20- Mannocci F, Bertelli E, Sherriff M, Watson T, Pitt Ford T. Threeyear clinical comparison of survival of endodontically treated teeth restored with either full cast coverage or with direct composite restoration. J Prosthet Dent. 2002;8:297-301.

21- Mannocci F, Ferrari M, Watson T. Intermittent loading of teeth restored using quartz fiber, carbon-quartz fiber and zirconium dioxide ceramic root canal posts. J Adhes Dent. 1999;1:153-8.

22- Marshall G Jr. The dentin substrate: structure and properties related to bonding. J Dent. 1997;25:441-58.

23- Ottl P. Fracture characteristics of carbon fiber, ceramic and nonpalladium endondontic post systems at monotonously increasing loads. J Oral Rehabil. 2002;29:175-83.

24- Paul S, Werder P. Clinical success of zirconia oxide posts with resin composite or glass-ceramic cores in endondontically treated teeth: a 4-year retrospective study. Int J Prosthodont. 2004;17:524-8.

25- Pontius O, Hutter J. Survival rate and fracture strength of incisors restored with different post and core systems and endodontically treated incisors without coronoradicular reinforcement. J Endodont. 2002;28:710-5.

26- Qualtrough A, Mannocci F. Tooth-colored post systems: a review. Oper Dent. 2003;28:86-91.

27- Sorensen J, Engelman M. Ferrule design and fracture resistance of endodontically treated teeth. J Prosthet Dent. 1990;63:529-36.

28- Strub J, Pontius O, Koutayas S. Survival rate and fracture strength of incisors restored with different post and core systems after exposure in the artificial mouth. J Oral Rehabil. 2001;28:120-4.

29- Wiskott HWA, Nicholls JI, Belser UC. Stress fatigue: basic principles and prosthodontic implications. Int J Prosthodont. 1995;8:105-16.

30- Xible AA VA, De Jesus Tavarez RR, Kano SC. Evaluation of shear bond strength of two post systems with two core build-up materials. J Dent Res. 2002;81(Special Issue A):A-250. 